\title{
Między znaczeniem leksykalnym a walencją - próba opracowania metody ekstrakcji ekwiwalentów na podstawie korpusu równoległego
}

\section{Cel}

Kontakt z językami obcymi wymaga ciągłej pracy przekładowej, która zwłaszcza w przypadku języków blisko spokrewnionych nierzadko bywa w nieoczekiwany sposób utrudniona (choćby za sprawą „fałszywych przyjaciół”). O ile większych kłopotów nie sprawiają rzeczowniki pospolite (tłumaczenie nazw własnych jest sztuką samą w sobie ${ }^{2}$ ), o tyle często problemy powodować może samo rozumienie, a co za tym idzie - również przekład czasowników - szczególnie opisujących stan psychiczny. Zdarza się, iż proponowanymi

1 Praca nad tym artykułem została częściowo dofinansowana z projektu Český národní korpus (LM2011023) czeskiego Ministerstwa Szkolnictwa, Młodzieży i Kultury Fizycznej, w ramach programu Projekty dużych infrastruktur dla nauki, badań i innowacji.

${ }^{2}$ O przekładzie nazw własnych - Cieślikowa A., Jak ocalić w tłumaczeniu nazwy własne, [w:] „Między oryginałem a przekładem” II, red. Filipowicz-Rudek M, Konieczna-Twardzikowa J., Kraków 1996, s. 311-320; Hejwowski K., Kognitywno-komunikacyjna teoria przekładu, Warszawa 2009; Lewicki R., Obcość w odbiorze przekładu, Lublin 2000; Zakharkevich A., Ocalone czy utracone nazwy własne w tłumaczeniach baśni Marii Konopnickiej „O krasnoludkach i sierotce Marysi”?, [w:] „Między oryginałem a przekładem” XV, red. Brzozowski J., Filipowicz-Rudek M., Kraków 2009, s. 303-318. 
w słownikach ekwiwalentami bywają jednostki znacznie różniące się znaczeniem $^{3}$. Nie oznacza to jednak automatycznie, iż w języku źródłowym dany leksem jest wieloznaczny (bądź że mamy do czynienia z homonimią); może mieć on znaczenie, które jest nieoddawalne w języku docelowym za pomocą jednego ekwiwalentu. W trakcie przekładu, wybierając jakikolwiek „ekwiwalent” podany w słowniku, tłumacz musi rezygnować z niektórych znaczeń ${ }^{4}$. W typowych słownikach dwujęzycznych brakuje również informacji o walencji; dodatkowo na ogół nie prezentują (z uwagi na oczywiste ograniczenia) wszystkich możliwych znaczeń wraz z przykładami, które mogłyby pomóc w wyborze odpowiedniego ekwiwalentu. Artykuł ten nie koncentruje się jednak wokół definicji samego ekwiwalentus. W pracy tej ekwiwalent (dalej także - odpowiednik) to jednostka tekstowa w języku docelowym zastępująca jednostkę tekstową w języku źródłowym z zachowaniem równoważności semantycznej na poziomie języka pomiędzy tekstem wyjściowym a tekstem docelowym

Celem artykułu jest sprawdzenie, czy (i ewentualnie w jaki sposób) walencja (rozumiana formalnie i semantycznie ${ }^{7}$ ) wpływa na przekład leksemów (tu - cza-

${ }^{3}$ O problemie tym również w: Ka czmarska E., Czeski czasownik zdát se $w$ przekładzie na język polski (na podstawie badań z wykorzystaniem czesko-polskiego korpusu równoległego InterCorp), „Studia z Filologii Polskiej i Słowiańskiej” 47, 2012, s. 247-261.

${ }^{4}$ Może się zdarzyć, iż rzeczywiste znaczenie leksemu leży na granicy czy styku pól znaczeniowych kilku innych leksemów drugiego języka, a wskazanie jednego ekwiwalentu jest niemożliwe.

${ }^{5}$ Szerzej na temat ekwiwalencji m.in. w: Baker M., In Other Words: A Coursebook on translation, London 1992; Catford J. C., A Linguistic Theory of Translation: An Essay In Applied Linguistics, London 1965; Da mbska-Prokop U., Mała encyklopedia przekładoznawstwa, Częstochowa 2000; Gentzler E., Contemporary Translation Theories, London - New York, 1993; Hejwowski K., Kognitywno-komunikacyjna..., op. cit.; Kiela r B., Nauczanie tłumaczenia: rozważania nad ekwiwalencja i ekwiwalentnym tekstem przekładu, [w:] Przyczynki do teorii i metodyki kształcenia nauczycieli języków obcych i tłumaczy w perspektywie wspólnej Europy, red. Grucza F., Warszawa 1993, s. 139-150; Koller W., The Concept of Equivalence and the Object of Translation Studies, „Target” 7, 2, 1995, s. 191-222; Nid a E. A., Dynamic Equivalence In Translating, [w:] An Encyclopaedia of Translation. Chinese-English / English-Chinese, red. Chan S.-W., Pollard D. E., Hong Kong 1995, s. 223-230; Pieńkoś J., Przekład i tłumacz we wspótczesnym świecie. Aspekty lingwistyczne i pozalingwistyczne, Warszawa 1993.

${ }^{6} \mathrm{Na}$ podstawie definicji: Translation is the replacement of textual material in one language (SL) by equivalent textual material in another language (TL) - Catford J. C., A Linguistic Theory of Translation: An Essay In Applied Linguistics, London 1965, s. 20; Tou ry G., In Search of Theory of Translation, Tel Aviv 1980, s. 63; cyt za: Da mbska-Prokop U., Mała encyklopedia..., op. cit., s. 68-75.

7 Dębski A., Semantyczna walencja czasownika w aspekcie konfrontatywnym, „Biuletyn Polskiego Towarzystwa Językoznawczego" XXXIX, 1982, s. 79-90; Rytel D., Wybrane 
sowników) oraz zaprezentowanie możliwości oddania w języku polskim pojęć w nim nieistniejących (por. przypis 4), a obecnych w języku czeskim - języku blisko spokrewnionym. W efekcie badań autorzy wypracują dane, które mogą być wykorzystane jako uzupełnienie tradycyjnych dwujęzycznych słowników.

Przedmiotem analizy jest czasownik toužit, rozumiany w języku polskim jako tęsknić, pragnać, marzyć ${ }^{8}$. W rzeczywistości jednak czasownik ten przekładany jest w różny sposób, co dokumentują przykłady z korpusu równoległego InterCorp'.

InterCorp to zapoczątkowany w 2005 roku projekt Uniwersytetu Karola w Pradze, a zarazem część Czeskiego Korpusu Narodowego. Jest to duży synchroniczny korpus paralelny, obejmujący 32 języki (stan na sierpień 2013). InterCorp zawiera różne teksty jednobrzmiące (literatura piękna, publicystyka, teksty administracyjne), których „parą” jest zawsze tekst czeski (bądź jako oryginał, bądź jako tłumaczenie). Język czeski jest dla InterCorpu językiem kluczowym. Aktualnie on-line dostępna jest wersja 5 (zawiera 543 miliony słów obcych i 97 milionów słów czeskich, w tym tekstów beletrystycznych - odpowiednio 92 i 53 miliony słów) oraz wersja 6 (zawiera 867 milionów słów obcych i 100 milionów słów czeskich, w tym tekstów beletrystycznych - odpowiednio 139 i 62 miliony słów). Wersja ta dysponuje wiązaniem segmentów na poziomie zdania, tagowaniem morfologicznym oraz lematyzacją ${ }^{10}$.

Korpus równoległy ma służyć, między innymi, jako źródło danych do badań teoretycznych, analiz leksykograficznych, poszukiwań studenckich, projektów dotyczących nauki języków obcych, a przede wszystkim - badań translatorskich ${ }^{11}$.

Wykorzystywana w tej pracy część InterCorpu to korpus czesko-polski, zawierający 29,6 milionów słów w polskich tekstach, z czego beletrystyka stanowi 8,4 miliony słów ${ }^{12}$. Materiałem poddanym badaniu będą właśnie przykłady z tego korpusu oraz pary ekwiwalentów wygenerowane automatycznie metodą wyrównania segmentów słownych - word-to-word alignment;

8 Oliva K., Polsko-český slovník, Praha 1994; Siatkowski J., Basaj M., Slownik czesko-polski, Warszawa 2002.

9 Čermák F., Rosen A., The case of InterCorp, a multilingual parallel corpus, „International Journal of Corpus Linguistics” 13 (3), 2012, s. 411-427.

10 Źródło i dostęp www.korpus.cz/intercorp

11 Podstawy językoznawstwa korpusowego, red. Lewandowska-Tomaszczyk B., Łódź 2005, s. 43.

12 Na potrzeby tego badania wykorzystywana była wersja 5 InterCorpu. Wersja 6 zawiera 47,6 miliona słów w ramach części czesko-polskiej korpusu, z czego beletrystyka stanowi 12,7 miliona słów. 
w nomenklaturze polskiej występuje w tym kontekście również termin wiązanie tekstó $w^{13}$. Metoda ta umożliwi frekwencyjną analizę problemu zasygnalizowanego w temacie w oparciu o wymogi walencyjne i semantyczne wyekscerpowanych leksemów.

\section{Analiza}

2.1. Pierwszy etap analizy obejmował ekscerpcję, którą autorzy ograniczyli do oryginalnie czeskich tekstów beletrystycznych z InterCorpu (1,7 mln słów w języku czeskim).

Chcąc przedstawić rozmiar materiału poddanego ekscerpcji, należy dokonać rozróżnienia na oryginały czeskie, polskie i inne (obce), występujące w języku czeskim i polskim. Dane liczbowe wyglądałyby następująco (wszystkie dane liczbowe oprócz frekwencji czasownika podane w milionach słów):

Tabela 1. Liczba słów (w milionach) w beletrystycznych tekstach w czesko-polskiej części korpusu InterCorp (wersja 5) oraz frekwencja czasownika toužit

\begin{tabular}{|c|c|c|c|c|}
\hline & $\begin{array}{c}\text { czeskie } \\
\text { oryginały }\end{array}$ & $\begin{array}{c}\text { polskie } \\
\text { oryginały }\end{array}$ & $\begin{array}{c}\text { obce } \\
\text { oryginały }\end{array}$ & $\sum$ \\
\hline w języku czeskim & 1709 & 1757 & 4917 & 8384 \\
\hline w języku polskim & 1783 & 1698 & 4903 & 8384 \\
\hline toužit & 248 & 146 & 418 & 812 \\
\hline
\end{tabular}

Wyszukiwanym lematem był, jak to zostało już wcześniej wspomniane, czasownik toužit. Podczas ekscerpcji manualnej (w tej fazie analizy) autorzy pomijali w wyszukiwaniu derywaty i wyrazy bliskoznaczne. W korpusie

problemy opisu walencyjnego języka, „Studia z Filologii Polskiej i Słowiańskiej” XXVI, 1989, s. 237-247; Walencja czasownika a problemy leksykografii dwujęzycznej, red. Rytel-Kuc D., Wrocław 1991; Z. Greń, D. Rytel-Kuc, Wykorzystanie przekładów literackich w pracy nad dwujęzycznym słownikiem walencyjnym, [w:] Problemy teoretyczno-metodologiczne badań konfrontatywnych języków słowiańskich, red. Běličová H., Nieszczimienko G., Rudnik- Ka rwatowa Z., Warszawa 1991, s. 69-78; Čer máková A., Valence českých substantiv, Praha 2009; Urbańczyk-Adach N., Wariantywność walencji czeskiego czasownika, Warszawa 2011; D a neš F., Hlavsa Z., Větné vzorce v češtině, Praha 1987.

13 Ibidem. 
Między znaczeniem leksykalnym a walencją - próba opracowania metody ekstrakcji... 107

równoległym czesko-polskim (czeski oryginał, tłumaczenia na język polski, tylko beletrystyka - dalej: BELcz $\rightarrow$ pl) znaleziono 248 poświadczeń czasownika toužit ${ }^{14}$.

Otrzymane wyniki zostały otagowane pod względem walencji czasownika czeskiego, następnie pogrupowane pod względem walencji i łączliwości z określonym obiektem. Autorzy wyróżnili następujące typy łączliwości:

- toužit po Oabstr (obiekt abstrakcyjny)

(1) Netoužím po tomhle slizkém bratrství.

Nie tęsknię za takim oślizłym braterstwem.

- toužit po Ohum (obiekt osobowy)

(2) Jsi krásná, neprestanu po to bě toužit a bát se tvé krásy, miluji tě až do smrti, ale ještě více tě nenávidím.

Jesteś piękna, nigdy nie przestanę cię pragnąć i bać się twojej urody, kocham cię aż do śmierci, ale bardziej cię nienawidzę.

- toužit po / do OR (obiekt realny)

14 Uzasadnione wydaje się w tym miejscu pytanie, czy InterCorp jest dostatecznie reprezentatywny do tego typu badania i czy reprezentacja różnych wzorów walencyjnych czasownika toužit $\mathrm{w}$ korpusie InterCorp jest porównywalna $\mathrm{z}$ danymi $\mathrm{z}$ jednojęzycznego korpusu języka czeskiego. Autorzy sprawdzili to na podstawie Czeskiego Korpusu Narodowego. W korpusie syn (dane z 19.03.2013) znajduje się 1568 milionów pozycji, przy czym czasownik toužit ma w nich 49196 poświadczeń, co wynosi 31,35 ipm (items per million); współczynnik ten nie jest większy od współczynnika dla InterCorpu (BELcz $\rightarrow$ pl), który wynosi 145,08 ipm. Można więc przyjąć, iż czasownik toužit reprezentowany jest w korpusie InterCorp w odpowiednim zakresie. Różnica wynika z tego, iż w korpusie syn jest o wiele mniejszy udział literatury pięknej, a termin pozycja obejmuje również znaki interpunkcyjne.

Druga wątpliwość dotyczy tego, jak wygląda rozkład procentowy różnych wzorów walencyjnych czasownika toužit w korpusie jednojęzycznym i InterCorpie. Autorzy brali pod uwagę wzory: toužit po + Locative, toužit + infinitiv, toužit + aby + S (zdanie). Oprócz obiektu „aby + zdanie" badano te wzory po obu stronach czasownika toužit. W rezultacie, przy konfrontacji wyników z korpusu syn z ekscerpcją ręczną z InterCorpu (BELcz $\rightarrow$ pl), okazało się, iż w korpusie syn i InterCorpie pojawia się podobna liczba wystąpień czasownika toužit z przyimkiem po i obiektem ( $60,05 \%$ vs 55,98\%) oraz toužit z bezokolicznikiem (31,59\% vs 30,89\%). Różnica występuje jedynie w przypadku wzoru toužit + aby + S (3,50\% vs $8,88 \%)$.

Trzeci problem dotyczyć może faktu, że do pewnego stopnia śledzimy uzus jednego autora (ewentualnie tłumacza). W poddawanej analizie części InterCorpu (BELcz $\rightarrow$ pl), w tekstach Milana Kundery wszystkie formy czasownika toužit pojawiają się siedmiokrotnie częściej niż we wszystkich innych tekstach. Kundera, jak wyniknie z przedstawionego podziału, używa mniej połączeń toužit + po $(52,05 \%$ vs $68,63 \%)$, natomiast więcej toužit + infinitiv (36,30\% vs $21,57 \%)$ oraz toužit $+a b y(10,96 \%$ vs. $8,47 \%)$. Różnice nie są diametralne, a wysoką częstotliwość tych form można potraktować jako dobrodziejstwo w kontekście badania tego typu. 
po $+\mathrm{OR}$

(3) Když jsem si to uvědomil, prepadlo mne málem zoufalství: cítil jsem se tu jako trosečník a toužil jsem najednou žíznivě po Praze, po své práci, po psacím stolku ve svém bytě, po knihách.

Kiedy to sobie uprzytomniłem, ogarnęła mnie niemalże rozpacz; czułem się tu jak rozbitek i nagle goraco zatęskniłem za Praga, za swoja praca, za biurkiem $w$ swoim mieszkaniu, za ksiażkami.

$d o+\mathrm{OR}$

(4) to tělo již toužilo do hrobu to ciało tęsknito już do grobu

- toužit $+\inf$ (bezokolicznik)

(5) Každýz nás touží překročit erotické konvence, erotická tabu, a vstoupit v omámení do království Zakázaného.

Każdy $z$ nas pragnie przekroczyć erotyczne konwencje, tabu, i w upojeniu wstąić w królestwo Zakazu.

- toužit $+\mathrm{S}$ (zdanie podrzędne $\left.{ }^{15}\right)$

toužit, aby

(6) Všechno, co se kolem ní dělo, ji obtěžovalo a rušilo a ona toužila, aby se nedělo nic. Wszystko, co działo się dookoła, zawadzało jej, męczyło, i pragnęła, by nie działo się nic.

toužit po tom, aby

(7) Nesmírnè toužila po tom, aby se s ní oženil, ale bála se, že kdyby k tomu došlo príliš záhy, cítil by se spoután a ztratila by ho pak tím jistěji.

Pragnęła bardzo, żeby się z niq ożenit, ale obawiała się, że o ile stanie się to za wcześnie, będzie się czut spętany, a ona straci go tym prędzej i tym pewniej.

Każda $\mathrm{z}$ grup została następnie przefiltrowana pod kątem polskiego ekwiwalentu (i jego walencji). Wyniki zostały przedstawione $\mathrm{w}$ tabelkach ukazujących, „które” toužit w jaki sposób jest przekładane.

\subsubsection{Możliwości rozumienia i przekładu frazy toužit po Oabstr (94 poświadczenia)}

Jest to najliczniejsza grupa i najbarwniejsza pod względem przekładu. W przypadku jednostki toužit łączącej się z obiektem abstrakcyjnym obser-

${ }^{15}$ Czasownik toužit, jak wynika ze zgromadzonego materiału, łączy się z frazą zdaniową na dwa sposoby - bezpośrednio - toužit, aby oraz pośrednio (ze wskaźnikiem zespolenia) - toužit po tom, aby. 
wujemy skłonność tłumaczy do wyboru ekwiwalentu pragnać (oraz jednostek bliskoznacznych, np. pożądać). Przybliżoną liczbę poświadczeń mają tutaj jednak także czasowniki marzyć i tęsknić (wraz z formami bliskoznacznymi). Na uwagę zasługuje fakt, iż w tej grupie znalazło się najwięcej jednostek tęsknić łączących się z przyimkiem do jako ekwiwalentów czasownika toužit. Pojedynczo pojawiają się także przykłady zawierające inne jednostki (m.in. dążyć do, dybać, myśleć, szukać, upragniony, zamierzać, żąny).

(8) tam již se ukláněl sám papežský nuncius Karel Caraffa, který tak dlouho toužil po pražských vavřinech, ale probošt již mluvil.

Ach, tam kłaniat się sam nuncjusz papieski Karol Caraffa, który tak dawno pragnął wawrzynów praskich, ale prepozyt już mówit.

(9) Ale zatím chce, abych život snášel a po smrti toužil. A tymczasem chce, bym życie znosit, a śmierci pragną.

(10) Toužili po hodnosti císařské, opakoval hrabě a apoštolskému misionáři táhly před očima nejpochmurnějš́ obrazy.

Marzyli o majestacie cesarskim - powtórzył hrabia, a misjonarzowi apostolskiemu przesunęty się przed oczami najstraszniejsze obrazy.

(11) a myslím, že není hříchem, toužíme-li v srdci svém po odpočinku a pokoji. i sądzę, że nie jest grzechem, jeśli w głębi serca tęsknimy za odpoczynkiem i spokojem.

(12) Toužila po světě, kde lidé mluví jinou řečí než on.

Tęskniła do świata, w którym ludzie mówią innym językiem niż on.

\subsubsection{Możliwości rozumienia i przekładu frazy toužit po Ohum} (37 poświadczeń)

Zgromadzone dane prezentują różne możliwości przekładu na język polski czasownika toužit, łączącego się z obiektem osobowym. Tłumacze najczęściej wybierali jako ekwiwalent jednostkę pragnać (również zapragnać) oraz wyrazy bliskoznaczne (pożądać, mieć ochotę) - w sumie jednostki te to $64,86 \% \mathrm{w}$ tej grupie. W przekładach pojawiają się również pozostałe, proponowane przez słowniki odpowiedniki, ale były wybierane zdecydowanie rzadziej (marzyć - 5,4\%, tęsknić - 29,72\%). Pojedynczo pojawiają się także przykłady zawierające inne jednostki (m.in. $\dot{z} y w i c ́$ miłość).

Na podstawie przeprowadzonego badania można by stwierdzić, że czasownik toužit łączący się z obiektem osobowym jest najbliższy znaczeniowo polskiemu czasownikowi pragnać, a także pożądać. Zdajemy sobie jednak sprawę, iż dysponując tak nielicznymi danymi, można spreparować całą regułę w oparciu o język danego tłumacza. Przyjrzyjmy się więc przykładom, a w nich kontekstom, w których czasownik toužit się pojawia: 
- afekt i kontekst erotyczny:

(13) Měl pocit, jako by právě po ní toužil už po mnoho let, jako by ji celou tu dobu hledal po celém světě.

Poczut, że to jej właśnie pragnął przez całe lata, że to jej szukał po całym świecie.

(14) Kdysi toužil jen po nových ženách.

Niegdyś pożądat tylko nowych kobiet.

(15) Toužila po něm.

Pragnęła jego obecności.

- sytuacje, w których pojawia się tęsknić (często części ciała, które „reprezentują" całą osobę):

(16) Oči, po kterých touží, jsou oči Tomáše.

Oczy, do których tęskni, to oczy Tomasza.

(17) Nemohl jsem najednou vůbec pochopit, proč jsem tak nepříčetně toužil po jejím těle;

Nie mogłem naraz absolutnie pojać, dlaczego tak niepoczytalnie pragnąłem jej ciała;

(18) Toužila po svém vlastním těle, náhle objeveném, nejbližším i nejcizejším a nejvíc vzrušujícím.

Tęskniła do własnego ciała, nagle odkrytego, najbliższego i najbardziej obcego, najbardziej podniecajacego.

- tęsknić za osobą (istotą), ale również bez kontekstu seksualnego:

(19) Tys neznala Boha, Lucie, ale toužila jsi po něm.

Tyś nie znała Boga, Łucjo, ale tęskniłaś do Niego.

(20) Proč by měl Goethe toužit po Herderovi?

Dlaczego zatem Goethe miałby tęsknić do pośmiertnej obecności Herdera?

(21) Dlouhé hodiny se jí v duchu zuřivě vysmival a dlouhé hodiny po ní zoufale toužil. Całymi godzinami naśmiewał się $z$ niej $w$ duchu i całymi godzinami rozpaczliwie za nią tęsknił.

- bardzo pragnać / chcieć:

(22) Copak tys nikdy netoužil po dítěti?

Czy nigdy nie pragnałeś mieć dziecka?

- marzyć jako opcja przekładu:

(23) Vždycky jsem toužila po člověku, který by byl prostý a př́mý.

Zawsze marzyłam o człowieku, który byłby prosty i bezpośredni.

(24) Není to proto, že by ženy, které se chtějí stát matkami, toužily po světlovlasých dětech s modrýma očima, ale protože existuje nedostatek spermatických bank. Bez obaw - przyszłe matki nie marza o błękitnookim i jasnowłosym potomstwie, po prostu w bankach spermy brakuje materiału. 
Między znaczeniem leksykalnym a walencją - próba opracowania metody ekstrakcji... 111

\subsubsection{Możliwości rozumienia i przekładu frazy toužit po OR (15 poświadczeń)}

W przypadku tej grupy trudno mówić o jakiejś tendencji. Wszystkie ekwiwalenty mają poświadczenia jednocyfrowe. Najwięcej przykładów zawiera jednostkę marzyć, ale pozostałe czasowniki, proponowane przez słowniki, są również obecne (pragnąć, tęsknić).

(25) Mladý muž touží po vlastním divadle.

Młody mężczyzna marzył o własnym teatrze.

(26) Celý život jsem toužila po skutečném domově,

Całe życie tęskniłam za prawdziwym domem,

(27) Mé patro, vyprahlé po noci zpola probdělé a zpola neklidně prosněné, toužilo po jejím vřelém a mrazivě vonném doušku.

Moje podniebienie, wyschnięte po nocy na wpótprzemarzonej i na wpót prześnionej, pragnęło jej goracego, orzeźwiająco wonnego łyku.

\subsubsection{Możliwości rozumienia i przekładu frazy toužit + inf (80 poświadczeń)}

W przypadku tej grupy możemy mówić o wpływie walencji na znaczenie i rozumienie tego czasownika. Czasowniki pragnąć, chcieć oraz konstrukcje formalnie im bliskie (także derywaty) to 90\% wszystkich ekwiwalentów w tej grupie.

(28) Netouží být po smrti ani s Paulem ani s Brigitou.

Nie pragnęła również spotkać się z Paulem ani $z$ Brigitte.

(29) Každýz nás touží překročit erotické konvence, erotická tabu, a vstoupit $v$ omámení do království Zakázaného.

Każdy $z$ nas pragnie przekroczyć erotyczne konwencje, tabu, iw upojeniu wstąpić w królestwo Zakazu.

(30) Začal znovu skicovat do náčrtníku obrazy, které toužil namalovat.

Zaczą znowu szkicować w notatniku obrazy, które pragnął namalować

(31) Já si taky umím představit, že si člověk touží vzít život.

Ja również mogę zrozumieć, że człowiek chce ze soba skończyć.

(32) Nemohu než to ještě jednou zdưraznit: netoužila vidèt pohlaví cizího muže. Nie moge nie podkreślić tego jeszcze raz: nie chciała ogladać organów płciowych obcego mężczyzny.

(33) když on toužil mluvit sprostě, ona zarputile mlčela gdy jemu zachciewało się wulgarnych słów, ona uparcie milczała

(34) Teprve během těch tři dnů s ním mohla být tak, jak s ním vždycky toužila být. Te trzy dni były jedynymi, które udało jej się spędzić przy ojcu w warunkach, o jakich zawsze marzyła. 
(35) Nakonec toužite poznat někoho obyčejnýho.

W końcu tęskni się za tym, by poznać kogoś zwyczajnego.

\subsubsection{Możliwości rozumienia i przekładu frazy toužit, aby / po tom, aby (23 poświadczenia)}

Dość wyraźne znaczenie wydaje się mieć czasownik toužit łączący się ze zdaniem podrzędnym. Przeważająca liczba przykładów zawiera czasownik pragnąć (lub chcieć), marzyć pojawia się dwa razy, natomiast tęsknić w zebranym materiale nie pojawia się w ogóle.

(36) Toužila tehdy, aby už jednou skončila ta nebezpečná cesta zrad.

Pragnęła wówczas, żeby raz wreszcie skończyła się ta niebezpieczna droga zdrad.

(37) Toužila, aby přšel, toužila, aby ji k sobě pozval!

Pragnęła, żeby przyszedł, pragnęła, aby zaprosit ja do siebie!

(38) Nesmírně toužila po tom, aby se s ní oženil.

Pragnęła bardzo, żeby się z niq ożenit.

(39) Touží, aby ji někdo odnaučil být anachronická!

Marzy, by ktoś nauczyt ja, jak nie być anachroniczna!

(40) I on toužil po tom, aby mu nejvy̌šsí soudy stranily a aby mu ústavní soudci byli po vưli. Jemu również marzył się odgórnie sterowany wymiar sprawiedliwości - na przykład pod postacią uległych mu sędziów Trybunału Konstytucyjnego.

2.2. Drugi etap analizy obejmował ekscerpcję z polskich oryginałów i ich przekładów na język czeski. Liczba słów w polskich tekstach oryginalnych jest w przybliżeniu równa liczbie słów w oryginałach czeskich (1,7 mln słów). Poszukiwane były polskie frazy, których czeskim ekwiwalentem w zebranym materiale był czasownik toužit (znaleziono 149 poświadczeń ${ }^{16}$ ). Dalsza metoda postępowania była identyczna jak w pierwszym etapie. Prowadząc badanie w odwrotnym kierunku (polski oryginał i jego przekład na język czeski), autorzy próbowali wyszukać, jakie jednostki z języka polskiego są przekładane jako czasownik toužit.

\subsection{1. toužit po Oabstr (57 poświadczeń)}

$\mathrm{W}$ ponad połowie przykładów w polskim wersji (oryginał) pojawia się jednostka pragnać (oraz chcieć, pożądać, spragniony). W oryginale występują też m.in.: marzyć o, tęsknić do / za, złakniony.

(41) Lid byl unaven, po zdařilé revoluci toužil po klidu a vydechnutí.

Ludność była zmęczona, po udanej rewolucji pragnęła spokoju i wytchnienia.

16 Z całkowej liczby 149 przykładów 6 nie podlega analizie. Były to błędy celowe autora oryginału polskiego (5 przykładów) oraz błąd wiązania segmentów tekstu (1 przykład). 
Między znaczeniem leksykalnym a walencją - próba opracowania metody ekstrakcji... 113

(42) Neuměl jsem toužit po čistých zvucích.

Nie potrafiłem pożadać czystych dźwięków.

(43) jiní její synové nebudou toužit po takových výpravách inni jej synowie nie o wyprawach takich będa marzyć

(44) jsme v podstatě hrozně citliví a toužíme po ušlechtilých citech krásných žen... jesteśmy bardzo czuli i tęsknimy do dobrych uczuć pięknych kobiet...

(45) Předstíral jsem lásku jako každý samec, který touží po kopulacji. Jak każdy złakniony kopulacji samiec pozorowałem miłość.

\subsection{2. toužit po Ohum (7 poświadczeń)}

Fraza ta jest najczęściej przekładem jednostek pragnąć i pożądać.

(46) Tolik jsem snila o této chvíli, tolik měsíců jsem po tobě toužila, tolik let jsem na to čekala, tolik jsem tím trpěla.

Ja tak marzyłam o tej chwili, tyle miesięcy pragnęłam cię, tyle lat czekałam na to, tyle cierpiałam przez to.

(47) O to se opírá princip trhání nebo pálení fotografií osob, které príliš nenávidíme, nebo naopak, po nichž príliš toužíme, než abychom mohli nosit jejich podobenky u sebe. Na tym polega zapewne darcie lub palenie fotografii osób zbyt znienawidzonych lub, odwrotnie, zbyt beznadziejnie pożądanych, by można było stale mieć ich podobizny przy sobie.

(48) A ona vběhla jako Lasička mezi stromy, ukryla se do jejich stínu a odtamtud po něm začala toužiti a vzdychati.

A ona między drzewa, co na placu były jak Łasica wbiegła $i$, w ich cień się schroniwszy, stamtąd tęsknić do niego i wzdychać zaczęła.

\subsection{3. toužit po OR (6 poświadczeń)}

W przypadku tej grupy nie można mówić o żadnej wyraźnej tendencji. W polskim oryginale znalazły się bowiem rożne jednostki (występujące w podobnych liczbach): chcieć, łaknąć, marzyć, pragnąć, przepadać.

(49) a všichni toužili po vodce, čaji a cigaretách.

a wszyscy łaknęli wódki, herbaty i papierosów.

(50) Chtěla si koupit šál, po kterém odedávna toužila.

Chciała kupić sobie szal, o którym od dawna marzyła.

\subsection{4. toužit $+\inf (58$ poświadczeń)}

Większość wyekscerpowanych przykładów z tej grupy w polskim brzmieniu posiada komponent pragnąć albo chcieć.

(51) Někdy už dokonce toužil prostě zavřit oči a zemřít, a nikdy už nevstat z mrtvých. Czasami pragnął już nawet, po prostu, zamknąć oczy i umrzeć, i nigdy nie zmartwychwstać. 
(52) Horši a menší národy žijí se svými zviŕaty a spolu s nimi touží být spaseny. Gorsze i mniejsze narody żyja ze swoimi zwierzętami i razem z nimi chcialyby zostać zbawione.

(53) Ǩekl, že to pak bývaly velmi vroucné modlitby a že ho nikterak netoužil usmrtit. Powiedział, że byly to bardzo żarliwe modlitwy i nie budziło się w nim wówczas pragnienie uśmiercenia jego istoty.

\subsection{5. toužit, aby / po tom, aby (11 poświadczeń)}

Również w tej grupie w polskich wersjach najczęściej występują jednostki pragnąć i chcieć. Pojawiają się też pojedyncze przykłady z czasownikami marzyć i tęsknić.

(54) Touží jen po tom, aby bylo všechno svědomitě zapsáno a zaplaceno. Pragnie jedynie, by wszystko zostało skrupulatnie odnotowane i zapłacone.

(55) Celý život toužila po tom, aby mohla studovat historii, teprve $v$ důchodu si však udělala dostatek času.

Całe życie chciała studiować historię, ale dopiero na rencie znalazła na to czas.

(56) Oni touží po tom, aby se nám nic nepovedlo a nakonec to dopadlo tak, že nám pošlou pohlednici s pozdravy a přáním všeho nejlepšího.

Marza o tym, żeby nic się nam nie udało, a przynajmniej, żeby na koniec wyszło na to, iż przyszła kartka z pozdrowieniami i życzeniami wszystkiego najlepszego.

(57) Kdopak by netoužil po tom, aby se ho dotkla, aby o něho zavadila Neviditelná Ruka? Któż nie tęskni za tym, żeby być dotkniętym, żeby być muśniętym przez Niewidzialną Rękę?

Reasumując, należy stwierdzić, iż toužit pojawia się najczęściej jako przekład polskich konstrukcji z chcieć, pragnąć, pożądać, tęsknić, marzyć. Warto jednak zwrócić uwagę na fakt, iż często polskie frazeologizmy oraz złożone składniowo i stylistycznie frazy tłumaczone są na język czeski jako toužit.

(58) Starannie obmyślałam pytanie, które pozwoliło by wydusić z niego więcej, nie dostarczajac zarazem żadnej wiedzy.

Zato jsem si bedlivě rozmýšlela dalši otázku, nebot' jsem toužila vydolovat z něj co nejvíc informací, ale zároveň sama neprozradila pokud možno vůbec nic.

(59) Z równa mnie odpowiedział ostrożnościa, że już to pewnie w tej potrzebie Matki naszej serce poczciwe Syna każdego do niej, do niej ptakiem się wyrywa.

Odvětil mi stejně opatrně, že ví, že v tuto těžkou hodinu potřebuje naše Matka každého svého Syna, jehož srdce po ní to uži a chce vzlétnouti jak Pták.

(60) Jak często i $z$ duma mawiał ojciec-miałem, czego dusza zapragnie, i nie brakowało mi ptasiego mleka.

Jak často a pyšně ř́íkával otec, měl jsem cokoli, po čem jsem toužil, včetně ptačího mléka. 
Po analizie jakościowej oryginalnie polskich tekstów i ich przekładów na język czeski, autorzy postanowili przeprowadzić prosty test frekwencyjny, badający częstotliwość pojawiania się różnych form czasownika toužit w przekładach $\mathrm{z}$ różnych języków (oraz w czeskich oryginałach tłumaczonych na te języki). Badaniu zostały poddane teksty z języka polskiego, niemieckiego, hiszpańskiego i rosyjskiego. W przypadku każdego języka obcego (dla języka czeskiego) częstotliwość występowania czasownika toužit jest mniejsza w przekładach (z tego danego języka) na język czeski niż w tekstach oryginalnie czeskich, por. Tabela 2.

Tabela 2. Różnice w użyciu form czasownika toužit w zależności od kierunku przekładu w różnych językach.

\begin{tabular}{|c|c|c|c|c|}
\hline język obcy & & $\begin{array}{c}\text { czeski } \\
\text { oryginał }\end{array}$ & $\begin{array}{c}\text { obcy } \\
\text { oryginał }\end{array}$ & $\begin{array}{l}\text { czeski oryginał } \\
\text { / obcy oryginał }\end{array}$ \\
\hline \multirow{3}{*}{ polski } & wszystkich słów razem & 1786732 & 1723278 & \\
\hline & liczba toužit & 251 & 145 & \\
\hline & ipm toužit & 140,48 & 84,14 & 1,67 \\
\hline \multirow{3}{*}{ niemiecki } & wszystkich słów razem & 2264607 & 4129923 & \\
\hline & liczba toužit & 291 & 284 & \\
\hline & ipm toužit & 128,50 & 68,77 & 1,87 \\
\hline \multirow{3}{*}{ hiszpański } & wszystkich słów razem & 572136 & 6177880 & \\
\hline & liczba toužit & 129 & 445 & \\
\hline & ipm toužit & 225,47 & 72,03 & 3,13 \\
\hline \multirow{3}{*}{ rosyjski } & wszystkich słów razem & 466519 & 765088 & \\
\hline & liczba toužit & 97 & 67 & \\
\hline & ipm toužit & 207,92 & 87,57 & 2,37 \\
\hline
\end{tabular}

\section{Wyniki ekscerpcji manualnej}

Podwójna ekscerpcja pozwoliła autorom na zgromadzenie par ekwiwalentów wybranych przez tłumaczy. Różnych odpowiedników czasownika toužit znaleziono ponad 30. Tabela 3. prezentuje najczęściej pojawiające się ekwiwalenty wraz z ich wymaganiami walencyjnymi. W pierwszej kolumnie znalazły się 
różne odpowiedniki czasownika toužit podzielone według walencji polskiego ekwiwalentu. Pozostałe dwie części tabelki przedstawiają liczbę przykładów, w których czeski czasownik toužit $\mathrm{z}$ walencją określoną w nagłówku kolumny był przełożony za pomocą określonego polskiego czasownika (wraz z jego walencją). Środkowa część tabeli to wynik badania pierwszego etapu, kiedy analizowane były teksty: oryginał - czeski, przekład - polski. Prawa część tabeli prezentuje wyniki badania drugiego etapu: przekład - czeski, oryginał - polski. Ostatnia kolumna, mająca w nagłówku X, ukazuje liczbę poświadczeń, w których czasownik nie był uzupełniony żadną frazą.

Tabela 3. Wyniki ekscerpcji manualnej

\begin{tabular}{|c|c|c|c|c|c|c|c|c|c|c|c|c|c|c|}
\hline toužit (po) & val & $\Sigma$ & $\mathrm{Oa}$ & $\mathrm{Oh}$ & OR & $\inf$ & S & $\Sigma$ & $\mathrm{Oa}$ & Oh & OR & inf & S & $\mathrm{X}$ \\
\hline chcieć & $\mathrm{Oa}$ & 0 & & & & & & 3 & 2 & & & & 1 & \\
\hline chcieć & inf & 23 & 1 & & 1 & 20 & 1 & 9 & 1 & & & 6 & 2 & \\
\hline chcieć & $S$ & 2 & & & & & 2 & 0 & & & & & & \\
\hline dą̇̇yć do & $\mathrm{Oa}$ & 2 & 2 & & & & & 0 & & & & & & \\
\hline laknąć & OR & 0 & & & & & & 2 & & & 2 & & & \\
\hline marzyć o & $\mathrm{Oa}$ & 24 & 20 & & & 4 & & 6 & 5 & & & 1 & & \\
\hline marzyć o & $\mathrm{Oh}$ & 3 & 1 & 2 & & & & 0 & & & & & & \\
\hline marzyć o & OR & 5 & & & 5 & & & 1 & & & 1 & & & \\
\hline marzyć & S & 3 & & & 1 & & 2 & 0 & & & & & & \\
\hline mieć ochotę & inf & 2 & & 1 & & 1 & & 1 & & & & 1 & & \\
\hline pożądać & $\mathrm{Oa}$ & 5 & 5 & & & & & 3 & 3 & & & & & \\
\hline pożądać & $\mathrm{Oh}$ & 5 & & 5 & & & & 2 & & 2 & & & & \\
\hline pragnąć & $\mathrm{Oa}$ & 33 & 29 & 1 & & 3 & & 26 & 25 & & & & 1 & \\
\hline pragnąć & $\mathrm{Oh}$ & 12 & & 12 & & & & 2 & & 2 & & & & \\
\hline pragnąć & OR & 3 & & & 3 & & & 1 & & & 1 & & & \\
\hline pragnąć & Inf & 53 & 4 & 1 & 1 & 44 & 3 & 24 & 1 & & & 23 & & \\
\hline pragnąć & $S$ & 15 & 1 & & & 1 & 13 & 3 & & & & & 3 & \\
\hline pragnąć & & 1 & & 1 & & & & 4 & & & & & & 4 \\
\hline
\end{tabular}


Między znaczeniem leksykalnym a walencją - próba opracowania metody ekstrakcji... 117

\begin{tabular}{|l|r|r|r|r|r|r|r|r|r|r|r|r|r|r|}
\hline \multicolumn{1}{|c|}{ toužit (po) } & val & $\Sigma$ & Oa & Oh & OR & inf & S & $\Sigma$ & Oa & Oh & OR & inf & S & X \\
\hline pragnienie & Oating & 0 & & & & & & 3 & & & & 3 & & \\
\hline (s)próbować & inf & 0 & & & & & & 2 & & & & 2 & & \\
\hline spragniony & Oa & 0 & & & & & & 3 & 3 & & & & & \\
\hline tęsknić do & Oa & 12 & 11 & 1 & & & & 2 & 2 & & & & & \\
\hline tęsknić do & Oh & 5 & & 5 & & & & 1 & & 1 & & & & \\
\hline tęsknić za & Oa & 7 & 7 & & & & & 1 & 1 & & & & & \\
\hline tęsknić za & Oh & 2 & & 2 & & & & 0 & & & & & & \\
\hline tęsknić za & OR & 2 & & & 2 & & & 0 & & & & & & \\
\hline złakniony & Oa & 0 & & & & & & 2 & 2 & & & & & \\
\hline INNE & & 27 & 9 & 7 & 2 & 7 & 2 & 35 & 10 & 2 & 2 & 20 & & 1 \\
\hline IN & & 219 & 81 & 31 & 13 & 73 & 21 & 145 & 45 & 5 & 4 & 36 & 7 & 5 \\
\hline
\end{tabular}

Wyniki przedstawione w tabeli 3. ukazują, iż wpływ walencji na przekład czasownika toužit widoczny jest najbardziej w przypadku łączliwości analizowanego czasownika $\mathrm{z}$ bezokolicznikiem; w tekście polskim najczęściej pojawiają się czasowniki pragnąć i chcieć łączące się również z bezokolicznikiem. Tylko sporadycznie występują w tym miejscu pozostałe odpowiedniki proponowane w słowniku tradycyjnym.

W przypadku łączliwości z pozostałymi obiektami trudno stwierdzić wpływ walencji na rozumienie i przekład tego czasownika.

\section{Automatyczna ekstrakcja ekwiwalentów z czesko- -polskiego korpusu równoległego}

Mając do dyspozycji korpus równoległy czesko-polski, autorzy podjęli próbę automatycznej ekstrakcji par ekwiwalentów; lista takich par to słownik wygenerowany metodą automatyczną ${ }^{17}$.

${ }_{17}$ Por. Jirásek K., Využití paralelního korpusu InterCorp kzískávání ekvivalentů pro chorvatsko-český slovník, [w:] Korpusová lingvistika - InterCorp, red. Čer mák D., Praha 2011, s. 45-55. 
Wykorzystanym narzędziem była GIZA $++^{18}$ - wiązanie segmentów na poziomie wyrazu (word-to-word alignment). GIZA++ jest wolno dostępnym programem, wytworzonym w celu statystycznego przekładu maszynowego, który zawiera moduł wiązania segmentów na poziomie wyrazu. Na wstępie czeskie i polskie teksty były w formie lematyzowanej ${ }^{19}$.

W trakcie ekstrakcji wykorzystane zostały teksty z korpusu InterCorp (wersja 6). Uwzględniona została jedynie beletrystyka (bez rozróżnienia na czeskie, polskie czy obce oryginały) - w tym teksty w języku czeskim: 11,885 milionów słów; teksty w języku polskim 11,860 milionów słów. Wiązanie segmentów (zdań) zostało ograniczone do 1:1, co zwiększa wiarygodność wiązania na poziomie zdania i wyrazu.

Metodą tą wyekstraktowano 8,651 milionów par lematów. Po złączeniu identycznych par (z zachowaniem informacji o ich liczbie) powstało 528 tysięcy haseł dwujęzycznych.

Tabela 4. Dwanaście najczęstszych ekwiwalentów czasowników toužit i pragnąć wyekstraktowanych automatycznie (BELcz $\rightarrow$ pl) z części korpusu InterCorp (wersja 6)

\begin{tabular}{|c|c|c|c|c|c|}
\hline 304 & toužit & pragnąć & 455 & pragnąć & chtít \\
\hline 107 & toužit & chcieć & 304 & pragnąć & toužit \\
\hline 82 & toužit & tęsknić & 281 & pragnąć & prrát \\
\hline 70 & toužit & marzyć & 55 & pragnąć & rád \\
\hline 40 & toužit & pożądać & 42 & pragnąć & snažit \\
\hline 24 & toužit & ochota & 18 & pragnąć & $a b y$ \\
\hline 9 & toužit & zapragnąć & 17 & pragnąć & potřebovat \\
\hline 8 & toužit & pragnienie & 16 & pragnąć & touha \\
\hline 8 & toužit & tęsknota & 13 & pragnąć & přání \\
\hline 8 & toužit & zależeć & 11 & pragnąć & pokoušet \\
\hline 7 & toužit & spragniony & 11 & pragnąć & prahnout \\
\hline 6 & toužit & $\dot{z} y c z y c ́$ & 11 & pragnąć & zatoužit \\
\hline
\end{tabular}

Wyekstraktowane pary porównano z wynikami ekscerpcji ręcznej.

18 Por. http://www.statmt.org/moses/giza/GIZA++.html; O ch F. J., Ney H., A Systematic Comparison of Various Statistical Alignment Models, „Computational Linguistics” 29, 1, March 2003, s. 19-51.

19 Do lematyzacji czeskich i polskich tekstów wykorzystano identyczne narzędzia jak w przypadku korpusu InterCorp. Zob. http://www.korpus.cz/intercorp/?req=page:info. 
Między znaczeniem leksykalnym a walencją - próba opracowania metody ekstrakcji... 119

Tabela 5. Porównanie ekscerpcji manualnej i automatycznej

\begin{tabular}{|l|r|r|r|r|r|r|}
\hline \multicolumn{1}{|c|}{ pol. } & cz.-pol. & pol.-cz. & wszystkie & \multicolumn{1}{c|}{ cz.-pol. } & \multicolumn{1}{c|}{ pol.-cz. } & wszystkie \\
\hline chcieć & 25 & 14 & 109 & $10,50 \%$ & $12,73 \%$ & $15,46 \%$ \\
\hline chęć & & 1 & 4 & & $0,91 \%$ & $0,57 \%$ \\
\hline dążyć & 2 & & & $0,84 \%$ & & \\
\hline łaknąć & & 3 & & & $2,73 \%$ & \\
\hline marzyć & 36 & 9 & 70 & $15,13 \%$ & $8,18 \%$ & $9,93 \%$ \\
\hline ochota & 2 & 1 & 24 & $0,84 \%$ & $0,91 \%$ & $3,40 \%$ \\
\hline pożądać & 10 & 5 & 42 & $4,20 \%$ & $4,55 \%$ & $5,96 \%$ \\
\hline pożądany & 1 & 1 & 2 & $0,42 \%$ & $0,91 \%$ & $0,28 \%$ \\
\hline pragnąć & 118 & 60 & 308 & $49,58 \%$ & $54,55 \%$ & $43,69 \%$ \\
\hline pragnienie & 3 & 4 & 8 & $1,26 \%$ & $3,64 \%$ & $1,13 \%$ \\
\hline (s)próbować & & 2 & & & $1,82 \%$ & \\
\hline spragniony & & 3 & 7 & & $2,73 \%$ & $0,99 \%$ \\
\hline szukać & 1 & & 4 & $0,42 \%$ & & $0,57 \%$ \\
\hline tęsknić & 32 & 5 & 82 & $13,45 \%$ & $4,55 \%$ & $11,63 \%$ \\
\hline tęsknota & & & 8 & & & $1,13 \%$ \\
\hline upragniony & & & 5 & & & $0,71 \%$ \\
\hline woleć & & 1 & 2 & & $0,91 \%$ & $0,28 \%$ \\
\hline żądny & 1 & & 2 & $0,42 \%$ & & $0,28 \%$ \\
\hline zależeć & & & 8 & & & $1,13 \%$ \\
\hline zapragnąć & 3 & 1 & 9 & $1,26 \%$ & $0,91 \%$ & $1,28 \%$ \\
\hline zatęsknić & 1 & & 5 & $0,42 \%$ & & $0,71 \%$ \\
\hline złakniony & 2 & & & $0,84 \%$ & & \\
\hline życzyć & 1 & & 6 & $0,42 \%$ & & $0,85 \%$ \\
\hline INNE & 14 & 8 & 22 & $5,88 \%$ & $7,27 \%$ & $3,12 \%$ \\
\hline RAZEM & 238 & 110 & 705 & $100,00 \%$ & $100,00 \%$ & $100,00 \%$ \\
\hline
\end{tabular}

Tabela 5. porównuje wyniki ekscerpcji ręcznej (cz.-pol., pol.-cz.) i automatycznej (wszystkie). Ekscerpcja automatyczna przeprowadzona została w oparciu o wszystkie teksty znajdujące się w czesko-polskiej części korpusu, ale stale była to tylko beletrystyka. Kolumny prezentują liczbę ekwiwalentów czasownika toužit przedstawionych w pierwszej kolumnie tej tabeli. Wyniki 
ekscerpcji automatycznej odpowiadają w przybliżeniu rezultatom ekscerpcji manualnej. Oznacza to, iż automatyczna metoda ekscerpcji ekwiwalentów przyniosła spodziewany efekt i należy oczekiwać, iż możliwe jest przeprowadzanie kolejnych badań w oparciu o nią. Mimo iż w obu metodach - manualnej i automatycznej - korzystano z nieidentycznych korpusów; do ekscerpcji automatycznej autorzy wykorzystali wszystkie teksty - oryginały i przekłady również z innych języków, jednak ciągle były to teksty beletrystyczne. Dodanie tekstów obcych było wskazane ze względu na to, iż wyniki metody automatycznej są bardziej wiarygodne przy większej ilości danych.

Metoda ta nie bierze jednak pod uwagę walencji, ale opiera się o kontekst. W dalszej fazie można by zamiast par leksemów ekstraktować pary istotnych kolokacji, natomiast w odleglejszej perspektywie wykorzystać syntaktycznie anotowane teksty (równoległy bank drzew - paralel treebank).

Automatycznie wygenerowany słownik można wykorzystać jako uzupełnienie konwencjonalnego dwujęzycznego słownika; dla użytkownika znającego obydwa języki, a poszukującego różnych znaczeń danego leksemu automatycznie wygenerowany słownik może mieć duże znaczenie (choćby w przypadku badań translatorskich czy frekwencyjnych). Może się okazać również niezastąpionym narzędziem w badaniach leksemów pewnego typu $\mathrm{np}$. zdrobnień (w tym przypadku korzystniejsze byłoby wykorzystanie sortowania a tergo).

\section{Podsumowanie}

Metoda zastosowana do opracowania danej próbki (tu - czasownika toužit) może być użyta do badania wszystkich relewantnych leksemów. Autorzy ustalili, iż wpływ walencji na wybór ekwiwalentu jest zauważalny najwyraźniej w przypadku formy toužit + infinitiv. Przy pozostałych schematach decydujące znaczenie może mieć wpływ szerszego kontekstu.

Automatyczną metodę ekstrakcji ekwiwalentów, która nie bierze pod uwagę walencji, autorzy postarają się w przyszłości rozszerzyć o ekstrakcję paralelnych kolokacji, która umożliwi bardziej precyzyjne badanie wpływu innych czynników, poza walencją, na wybór danego ekwiwalentu. 


\section{Between lexical meaning and valency \\ - towards a method for extracting equivalents based on a parallel corpus}

\section{(Summary)}

Some entries in translation dictionaries (even in those for closely related languages) offer multiple target equivalents with disparate meanings even when the meaning of the source word is not considered ambiguous within the source language. The translator's task of choosing the best fitting text unit is made even more difficult by sparse exemplification and missing or sketchy valency information. Using a parallel corpus, we explore to what extent valency (seen in a broad sense both as a syntactic and semantic property) can help to cope with a few difficult cases of Czech psych verbs in relation to Polish and how the lexical caps can be filled. Next, we compare the manually compiled lists of translation equivalents in context, annotated and sorted by their valency properties, with results of an automatic method, using word-to-word alignments in a lemmatised parallel corpus to build a list of equivalent pairs, annotated by their frequency. We conclude that valency is an important (though not omnipotent) discriminant for the choice of the target equivalent and that the list of translation pairs extracted automatically from a parallel corpus can be a useful supplement to a standard translation dictionary. 